\title{
THE COVID-19 PANDEMIC IN PUERTO RICO: EXCEPTIONALITY, CORRUPTION AND STATE-CORPORATE CRIMES
}

\author{
Jose Atiles Osoria
}

\begin{abstract}
The COVID-19 global pandemic brings about a new episode in the multi-layered political, economic and humanitarian crisis affecting Puerto Rico since 2006. The 14-years-long crisis has been marked by the U.S. and P.R. governments' imposition of a permanent state of exception to deal with an economic crisis, bankruptcy, hurricanes, swarms of earthquakes and a pandemic. This paper argues that uses of the state of exception and executive orders created a regime of permission for corruption, state-corporate crimes and human rights violations, while exacerbating the impact of the pandemic, and manufacturing the conditions for further disasters. The paper engages in a sociolegal analysis of the cases of corruption and state-corporate crimes in the procurement of COVID-19 test-kits and medical equipment, and the role of the pharmaceutical corporations in undermining PR's capacity to react to the COVID-19 pandemic.
\end{abstract}

Keywords: state of exception; state-corporate crimes; corruption; colonialism; pharmaceutical industry

\section{Introduction}

On July 11, 2020, while Puerto Rico (henceforth PR) ${ }^{1}$ recorded its highest-ever seven-day average of new coronavirus cases since the pandemic began, ${ }^{2}$ Governor Wanda Vázquez told the press that "the increase in COVID-19 cases is not the responsibility of the government, but rather, it is the responsibility of each citizen and business to comply with security protocols". 3 Similarly, Vázquez scolded Puerto Ricans for not taking the necessary individual measures to avoid contracting and spreading COVID-19, falsely arguing 4 that the government and her administration had done everything to address the pandemic, and that it was time to move on with the reopening of the economy. Later on, Governor Vázquez issued executive order OE-2020-54 of July 16, 2020, in which her administration reopened certain sectors of the economy and imposed additional changes to the existing emergency measures. ${ }^{5}$ These policies and the emphasis of this executive order

Jose Atiles Osoria, Visiting Assistant Professor of Criminology, Law and Society, Department of Sociology, University of Illinois at Urbana-Champaign 
on individual responsibility have generated over 26,326 confirmed cases of COVID-19, and over 720 deaths by October 9, 2020. ${ }^{6}$ However, Vázquez's administration executive orders ${ }^{7}$ continue arguing that the Puerto Rican government has done everything to protect public safety.

The uses of the state of emergency and executive orders, and the emphasis on individual responsibility and resilience have become key emergency measures to deal with any crisis in PR. The use of these emergency measures to contain the impact of the COVID-19 pandemic has further eroded Puerto Rican internal democracy and exacerbated previously existing forms of state violence, inequality and vulnerabilities. An example of the systemic erosion of internal democracy and the normalisation of emergency measures is that between March 12 and October 16, Governor Vázquez issued 45 executive orders ${ }^{8}$ to address the COVID-19 pandemic. $^{9}$

Simultaneously, the governmental management of the COVID-19 pandemic has generated multiple cases of corruption and state-corporate crimes. As former governmental employee turned disaster capitalist, Juan Maldonado, mentioned in March 2020, after being awarded a \$38 million contract with the Puerto Rican government to supply one million COVID-19 test-kits: "the virus was [and continues to be] productive". ${ }^{10}$

This paper examines the sociolegal and criminogenic impact of the emergency measures implemented by the U.S. and Puerto Rican governments to manage the COVID-19 pandemic. My contention is that in the Puerto Rican colonial imaginary, the state of emergency and executive orders have become the only tools to deal with any crisis affecting the island. This normalisation has manufactured a regime of permission ${ }^{11}$ or a framework for corruption, state-corporate crimes and human rights violations. Therefore, in PR, corruption and state-corporate crimes ought to be understood not only as consequences of specific moments of rupture or disaster, but as intrinsically embedded in colonial rule, neoliberal rationality and the administrative ethos of the U.S. and P.R. governments.

This paper analyses the governmental management of the pandemic in four parts. First, the paper shows the intertwined relationship between the state of exception, corruption, state-corporate crimes and disasters. Second, it provides a brief overview of P.R. recent history, and its management of the multi-layered crisis. Third, the paper describes the uses of the state of exception and executive orders by the P.R. government to address the COVID-19 pandemic. Finally, it engages with the empirical analysis of cases of corruption and state-corporate crimes in the procurement of COVID-19 test-kits and medical equipment, and the role of pharmaceutical corporations in undermining PR's capacity to react to the COVID-19 pandemic. All of this aims to show the way in which exceptionality, disaster and corruption have become an intrinsic part of everyday life in PR. 


\section{State of Exception as Framework for Corruption and State- Corporate Crimes}

The management of the COVID-19 global pandemic by countries of the global north and south has been heavily based on the uses of the state of emergency, executive orders, militaristic rhetoric and the private sector and corporations (Agamben 2020; Appadauri 2020; Maitra 2020). ${ }^{12}$ The implementation of emergency measures, and the neoliberal rationality behind them, has generated multiple debates on the constitutionality of the state of exception and its impact on democratic governance (Maitra 2020). Interestingly, these debates have neglected the relationship between the state of exception, corruption and state-corporate crimes. The few studies that look at the relationship between corruption and the COVID-19 pandemic mainly emphasise the role of individuals,,$^{13}$ overshadowing the role of organised deviance and the crimes of the powerful (Pearce 1976; Whyte 2009). Furthermore, we continue to lack a proper account of the uses of the state of exception in colonial settings, its connections to political economies of imperialism and how this dispositive propels corruption and state-corporate criminality as a form of governmentality.

By analysing the case of PR, this paper aims to make a twofold contribution. First, to shed light on the normalisation of the uses of the state of exception to administrate every aspect of colonial life-from legal design and economic development, to economic crises and disasters. Second, to show how the uses of the state of exception have become the legal framework for corruption and statecorporate crimes. This paper particularly looks at the alleged cases of governmental corruption and pharmaceutical profiteering in the P.R. management of the COVID19 pandemic.

Liberal conceptualisations of the state of exception depart from the understanding that crises and emergencies are moments of rupture within the normal function of democratic regimes. ${ }^{14}$ In this restrictive understanding of state power and law, the state of exception is understood as the suspension of the rule of law and civil rights to deal with situations that exceed the "normal" function of the rule of law, such as: political violence, natural disasters and economic crises (Agamben 2005, 2020). The uses of executive orders and invocations of states of emergency for the management of these emergency situations, liberal scholars argue, have normalised the constitution of spaces of indistinction or anomie between the legal and extra-legal. As Agamben (2005) suggests, these exceptional measures have been normalised in contemporary liberal-democracies, becoming - as the management of the COVID-19 pandemic by global north and south countries demonstrate- the dispositive of administration and governance of public and political life..$^{15}$

In tandem with this, the uses of the state of exception to deal with crises, such as the COVID-19 pandemic or economic crises, have become the legal dispositive 
par excellence of the neoliberal era (Ong 2006; Whyte 2010). Thus, creating a space/time in which regulatory policies are not implemented, or their application is suspended. The neoliberal rationale behind this is that crises and emergency situations need to be addressed through extra-legal mechanisms and technocratic measures, so that the economy and capital accumulation can continue (Maitra 2020). Thus, governmental declarations of the state of exception, although tailored to address the preservation of public health in the public eye, are in reality and practice constructed to maintain existing practices of capitalist accumulation, and structures of domination.

Contrary to liberal democracies, the state of exception has always been the norm in colonial settings (Reynolds 2017). Colonies and racialised colonial subjects have been placed in a permanent space of anomie, in which their inclusion within the colonial legal system has been possible through their exclusion. Thus, the coloniser always decides which laws and rights do or do not apply to the colonial space (Atiles 2016a, 2018; Jiménez 2020; Whyte 2010). In my own analysis of the legal constitution of U.S. colonialism in PR, the management of the Puerto Rican economic crisis and the historical process of the criminalisation of anticolonial movements, I have shown that a double exceptionality operates in PR. A colonial state of exception, which refers to the US's uses of this dispositive as a colonial domination technique (the legal-colonial design of PR, economic development, tax policies and the criminalisation of anticolonial movements) and an internal state of exception, which refers to the uses of this paradigm by the Puerto Rican government to manage crises and disaster, and to criminalise sociopolitical movements. In short, Puerto Rican economic, political and legal development has been based on a normalised state of exception (Atiles 2018). Furthermore, the internal state of exception has also defined the legal framework or the regime of permission that enables the creation of a tax-haven-like economy, state-corporate crimes and corruption. That is, PR's government and the local elites have resorted to the internal state of exception to promote economic development and the survival of the colonial economy in times of neoliberal crisis.

The framework of the regime of permission developed by Whyte (2014) to describe the dynamics of state-corporate crimes in capitalist societies serves as a useful lens to analyse the intertwined relationship between exceptionality, corruption and state-corporate crimes in PR. Whyte (2014: 244) argues that regimes of permission

allow us to see how an understanding of the state-corporate relationship at the level of "moments of rupture" clearly has its limits. It does not allow us to break down the formal (liberal) separation between the "state" and the "corporation" and move towards an understanding of the relation as a symbiotic one... 
A broader understanding of state institutions must therefore take account of the ways in which the infrastructural power of states themselves renew the formative conditions of corporate crime-described here as "regimes of permission".

This framework shows the symbiotic relationship between the state and corporations, and contributes to the literatures on state initiated and facilitated corporate crimes, and corporate initiated and facilitated state crimes (Green and Ward 2004; Lasslett 2012; Michalowski and Kramer 2006). This symbiosis is clearly portrayed in the tax incentive and regulatory policies legislated by the U.S. and P.R. governments for the pharmaceutical sector in PR. ${ }^{16}$

Similarly, in his analysis of the crimes of neoliberal occupation of Iraq, Whyte (2007) shows two important aspects of the relationship between exceptionality, regime of permission and state-corporate crimes. First, Whyte (2007) shows how executive orders and the state of exception created a liminal space for plunder, dispossession and wealth extraction in Iraq. Second, the author shows how corruption, contrary to mainstream analysis, is not the result of exogenous practices, but is rather intrinsically embedded in the neoliberal rationality, and key to capital accumulation. Whyte (2015) further expands his analysis of the political economy of neoliberal corruption, arguing that,

[r]ather than simply being understood as the peripheral consequence of various neoliberal experiment, corruption is an ever-present feature. Moreover, various forms of corruption are used as a means to maintain the strategically dominant position of particular elite group. In another words, corruption in those contexts can be understood as a form of power-mongering: a means of maintaining economic and political dominance (Whyte, 2015: 11).

In this sense, Whyte's (2015) understanding of corruption emphasises the crimes of the powerful and opposes individualistic (petty corruption) and reductionist conceptualisations of corruption and anti-corruption. Following this conceptualisation, this paper shows how in PR, corruption and state-corporate crimes are part of the neoliberal-colonial structure made possible by the internal state of exception. The paper argues that the uses of the state of exception to manage the COVID19 pandemic have not only created the opportunity for corruption and state-corporate crimes - an argument defended by disaster capitalist literature ${ }^{17}$ but have also manufactured further crises and disasters.

It is important to note that the uses of the state of exception and regime of permission to frame and describe the practices of corruption and state-corporate crimes in PR should not be understood as a simply bureaucratic or technical issue that can be quickly solved by better laws and regulations. Rather, this conceptualisation 
aims to shed light on specific forms of colonial plunder, wealth extraction by local elites and corporations, and structural violence based on the legal rhetoric of the rule of law and democracy.

There are important studies on the entwined relationship between disaster and state crimes. Green and Ward (2004: 56) have pointed out that natural disaster and state crimes can take place, among others, under the following circumstances: systemic corruption, state-corporate crimes, negligence, post-disaster cover-ups and concealment of evidence. Similarly, Green and Ward (2004) argue that three fundamental conditions which enhance a population's vulnerability to natural disaster are poverty, corruption and political authoritarianism. PR fulfils these categories and can even expand our understanding of the impact that corruption and state-corporate crimes have in exacerbating crises and disasters in colonial settings.

\section{Multi-layered Crisis in PR: A Short Historical Overview}

When the COVID-19 global pandemic arrived, PR was in a more precarious position than any other state or territory of the US. For example, PR was unprepared to face a $\$ 9.7$ billion direct economic impact, the loss of approximately $\$ 2$ billion in tax revenue ${ }^{18}$ and the permanent loss of over 100,000 jobs. ${ }^{19}$ Additionally, in 2018, 43 percent of residents ${ }^{20}$ and 57 percent of children ${ }^{21}$ in PR lived in poverty (Balmaceda 2020a). This unpreparedness is the result of a multi-layered ${ }^{22}$ politi- $^{2}$ cal, financial, economic and humanitarian crisis and the systemic uses of the internal state of exception and emergency measures to manage every aspect of it. The multi-layered crisis began in 2006 with an economic and financial crisis.

The current 14 years-long economic crisis is the result of: the U.S. Congress' decision, in 1996, to eliminate the tax exemption law Section 936 of the U.S. Internal Revenue Code (1976); ${ }^{23}$ the high level of public indebtedness; and the local impact of the global economic crisis of 2008 (GAO 2018). Section 936, which sought to encourage U.S. corporations to establish themselves in PR with the promise of repatriating profits as soon as they were made, was particularly directed at banking, financial services and pharmaceutical industries. ${ }^{24}$ Section 936 contributed to normalising the colonial tax-haven economy (Atiles 2020). As Dennis (2020b: 4) has shown:

70 medical device plants and 46 biopharmaceuticals operate in the island, which, taken as an industry, produce 11 of the 20 most necessary medicines worldwide. In 2019 exports of the pharmaceutical industry totalled $\$ 47$ billion, or $74 \%$ of the total exports of PR. In 2018, 36\% of the value of all manufactured products came from pharmaceuticals and medical equipment. 
The presence of the pharmaceutical industry in PR is relevant for this paper, since two of the major COVID-19 test-kit producers, Abbott and Roche, have been operating in the island under numerous tax exemptions, even after the elimination of Section 936, since the mid-20th century. For example, these companies still enjoy Law 135 of 1998 and Law 73 of 2008, which reduce the company's maximum income tax rate to 4 percent and grant tax credits for job creation and for the purchase of manufactured products in PR. In 2017, the fiscal cost for the tax exemptions provided under these two laws was around $\$ 15.7$ billion (Dennis 2020b). This amount is more than double the government's operating budget for a fiscal year. Abbott and Roche are also subject to Law 154 of 2010, which imposes a 4 percent tax on foreign corporations; however, the Federal Treasury reimburses it with a tax credit, meaning that, in the end, it does not imply a loss for the companies (Dennis 2020b).

While these corporations receive huge tax exemptions and corporate welfare, Puerto Ricans have been enduring the violence of austerity ${ }^{25}$ for the last two decades. That is, P.R. history has been marked by: (1) the intensification of neoliberal policies, such as budgetary cuts, the privatisation and externalisation of public services, low corporate taxation, and high dependence on bonds and debt issuance; (2) the legislation of exceptional laws to deal with the economic crisis and with every other aspect of political life - that is, every governor since 2006 has declared the state of financial emergency and used executive orders to manage the crisis (Atiles 2020); and (3) the exacerbation of the state-corporate criminality endemic of colonial systems. These measures led to the bankruptcy of the P.R. government in 2016, when the public debt amounted to $\$ 72$ billion and the per capita debt burden was $\$ 15,637 .{ }^{26}$

After the default in 2016, U.S. Congress passed the Public Law No. 114-118, known as Puerto Rico Oversight, Management, and Economic Stability Act (PROMESA). PROMESA is the US's colonial solution to address PR's crisis, and it is accompanied by the imposition of a Financial Oversight and Management Board, composed of seven members in charge of regulating the budget and funds of PR's government. The Board is a colonial body of emergency managers in charge of ensuring the survival of the Puerto Rican capitalist and financial system, as well as guaranteeing the payment of the debt and getting PR back into financial and stock markets.

Against this background, in September 2017, Hurricanes Irma and María practically destroyed the archipelago (Bonilla and LeBrón 2019). On top of that, PR has faced long delays in U.S. federal aid to rebuild infrastructure affected by the hurricanes, numerous corruption cases (Aronoff 2017; Klein 2018) and the criminal negligence that generated over 4,645 deaths (Kishore et al. 2018). The cases of corruption still affect PR's recovery to this day. As Rodriguez (2020) shows, the 
U.S. government has stopped the transfer of recovery funds given the lack of accountability and compliance in the P.R. government. The mishandling of hurricane María, the multiples cases of corruption and the leak of a now infamous chat $^{27}$ generated an anti-corruption mobilisation that resulted in the resignation of Governor Ricardo Rosselló in July 24, 2019.

Wanda Vázquez, former secretary of justice, became governor in August 2019, after Ricardo Rosselló resigned. As previous governors before her, on December 31, 2019, Vázquez issued a declaration of the state of emergency to deal with the economic crisis (OE-2019-66). This declaration of the state of emergency is the fifth extension since the Puerto Rico Financial Emergency and Fiscal Responsibility Act (Law 5 of January 29, 2017) was passed. ${ }^{28}$ Later on, on June 30, 2020, amidst the COVID-19 pandemic, Vázquez's administration issued executive order OE-2020-50, which extended for the sixth time the state of fiscal emergency until December 31 of 2020 . These executive orders symbolised the continuation of austerity measures and the permanent state of emergency imposed since 2006 to deal with the economic crisis.

Finally, in January 2020, a series of earthquakes devastated the island's southwestern region (Onís et al. 2020), worsening the already precarious economic and sociopolitical situation PR was living under. Governor Vázquez issued 18 executive orders between January 7 and March 12, 2020, and declared yet another state of emergency to address the disaster left by the earthquakes. ${ }^{29}$ The fact that PR has been enduring the violence of austerity and a permanent state of exception to deal with previous disasters exacerbated the impact of COVID-19. Under these precarious conditions, Puerto Ricans have been asked to be resilient, to withstand disasters (without the protection of the U.S. and P.R. governments), and to be responsible for themselves, their communities and the local economy.

\section{COVID-19, Exceptionality and Human Rights Violations}

Right from the beginning of the COVID-19 pandemic, Vázquez's administration declared a state of emergency (OE-2020-20, March 12, 2020). This declaration of the state of emergency has already been extended and modified in 16 instances since its initial invocation on March $12 .{ }^{30}$ Additionally, as mentioned above, between March 12 and October 1, Governor Vázquez issued 44 executive orders. All of these executive orders used Law 20 of April 2017 as the basis for the declaration of the state of emergency.

Law 20 was passed April 10, 2017 with the intention of creating the Puerto Rico Department of Public Safety (a consolidation of all the different security and public safety agencies). Among the agencies included in this reorganisation is the police department, which has been under Federal Court mandated reform since 
2012 after the American Civil Liberties Union (ACLU) sued for civil rights violations (Kilometro Cero 2018). This law is important for two reasons. First, by grouping together the P.R. police department, the Bureau of Special Investigations and the Institute of Forensic Sciences, the law technically eliminates the independence of the last two to conduct investigations against the police. This created the conditions for lack of accountability and impunity (Kilometro Cero 2018).

Second, in article 6.10, the law gives extraordinary power to the governor in case of an emergency. Aside from reaffirming the power of the governor to declare the state of emergency, in article 6.10, section b, the law established that the governor can: amend and revoke regulations, and amend and rescind orders he or she deems convenient to govern during the state of emergency or disaster. The regulations or orders issued during a state of emergency or disaster will have force of law while the emergency or disaster lasts. Furthermore, sections e and f confer power to the governor to acquire properties without the required due process in times of crisis, which was exactly what happened during the crisis generated by Hurricane María, when Rosselló's administration used and abused these executive powers, generating several corruption cases (Klein 2018). Similar corrupt patterns would arise during the swarm of earthquakes and the COVID-19 pandemic as well.

As the local administration has issued emergency measures, Puerto Ricans have been facing exponential increases in unemployment rates; lack of access to testing and proper monitoring of people infected by COVID-19 (Martinez 2020; Serrano 2020; Valentín and Minet 2020); a dramatic escalation of families facing food insecurity (Balmaceda 2020b); and unequal federal emergency relief (Gelardi 2020). For example, a considerable portion of Puerto Ricans did not receive the economic support provided by the CARES Act ${ }^{31}$ or any other federal aid relief. The different measures taken by Vázquez's administration to deal with COVID19 not only violated human rights, but also entailed the systemic erosion of an already degraded internal democracy and the hyper-exacerbation of an authoritarian style of governing. A short overview of some of the executive orders issued during these months can shed light on the normalisation of the state of emergency, corruption and abandonment of Puerto Ricans.

For example, executive orders OE-2020-22 and OE-2020-28 activated the P.R. National Guard (PRNG), allowed the Department of Health to uses medical resources from the PRNG, and further militarised public order/security. OE-202023 of March 15, 2020 established a lockdown for 14 days, as well as a curfew from 9pm to 5am. Executive order OE-2020-24 deregulates procurement processes and the purchase of essential materials, such as test-kits and personal protective equipment (PPE). It was in this context that the above-mentioned corruption case of Apex corporation took place. At the same time, OE-2020-27 deregulates the process of hiring external experts to manage the crisis. There is a pattern in the 
strategies implemented by the administration to deal with periods of emergency, consisting of: (1) militarisation; (2) deregulation; (3) and opening the gates for "external experts" to perform their profession in PR. The recent history of PR shows that contracting and bringing external experts has created opportunities for corruption (Klein 2018).

In parallel, OE-2020-26 created a Medical Task Force to advise the executive branch on how to combat COVID-19 (also see OE-2020-031). In tune with disaster capitalism practices, members of the Medical Task Force have already been tied to cases of alleged corruption regarding the purchase of test-kits and ventilators (Valentín 2020; Valentín and Cintrón 2020).

Executive order OE-2020-29 of March 30, 2020 expanded the lockdown for another 14 days, modified the curfew from $7 \mathrm{pm}$ to $5 \mathrm{am}$, and imposed additional limitations to "outdoors activities", including limiting the circulation of cars on designated days based on their license plate. More restrictions came with OE-202032 , which enforced the mandatory closure of essential services for the weekend of April 10 to 12 . These draconian measures not only generated a chaotic situation in local grocery stores, but also put Puerto Ricans in a dire humanitarian crisis, to the point that Vázquez's administration had to retract the emergency measures.

Furthermore, Vázquez's administration decided to grant immunity from civil cases to "medical facilities and professionals" providing services to COVID-19 patients through executive order OE-2020-36. This provision generated discomfort among Puerto Ricans, since it does not guarantee access to PPE or hazard pay for health care workers, but rather focuses on guaranteeing immunity to corporations that administer private hospitals (Wiscovitch and Sosa 2020). ${ }^{32}$ Similarly, OE-2020-40 of May 15 delineated the process to distribute the $\$ 2$ billion relief funds under the CARES act. The strategic plan not only set up an unequal distribution of the funds (giving more funds to private entities, including hospitals, than to public hospitals and public corporations [Dennis 2020a]), but also created a new Committee for the Oversight of Disbursements. The Committee, made up by members of Vázquez's administration, would need to establish new accountability and oversight processes, ignoring previously existing emergency relief agencies, such as COR3, and which would certainly further delay the distribution of funds.

Ignoring the recommendations of its own Medical Task Force, and pressured by the private sector (mainly the P.R. Manufacturers' Association, the Pharmaceutical Industry Association of P.R. [Abbott and Roche are part of this association], and the Private Sector Coalition), Vázquez issued executive orders OE-2020-37 and OE-2020-38, establishing the process "to reopen the economy". Executive order OE-2020-41 of May 21 provided more guidelines for the reopening of the "economy", while still maintaining curfew (7pm to 5am). OE-2020-44 of June 12 amended the curfew from 10pm to $5 \mathrm{am}$, and led the way to an almost 
complete reopening of the "economy". Simultaneously to the reopening of the economy, the curfew was extended by every executive order until October 16 by OE-2020-76. This emergency measure has been intensely criticised by Puerto Rican civil and human rights organisations (Comision de Derecho Civiles 2020; Kilometro Cero 2020).

As the executive branch has been issuing executive orders, the local legislature approved Law 35 of April 5, 2020, imposing serious penalties on those who disobey an executive order. As a result, hundreds of Puerto Ricans have been arrested, fined and even sent to prison for violations to the curfew (Florido 2020). ${ }^{33}$ All of this is taking place as citizens are enduring the effects of a quarantine without the necessary information, resources and access to essential services and testing.

The reopening of the economy comes alongside PR's lack of implementation of expansive testing and contact-tracing mechanisms, just as the local government has not provided the transparent and necessary information on reported cases (Dennis 2020b; Sosa and Wiscovitch 2020). PR lacks the urgent and robust testing capacity, the necessary ventilators and PPE to care for patients and frontline workers, and does not know when the peak of infection will be reached. ${ }^{34}$ The reckless moves by Vázquez's administration evidence a negligent and chaotic (mis)management of the pandemic, which backfired in July, when the government had to walk back on reopening the "economy" (OE-2020-54) given the accelerated escalation of COVID-19 infections and new cases. Nevertheless, the government decided, in the executive order OE-2020-66 of September 11, to completely reopen the economy and the country. 35

The uses of the state of emergency by Vázquez's administration shed light on the colonial-neoliberal and sociolegal transformations PR is experiencing, and on the normalisation of emergency measures as government policy. It is clear that the normalisation of the state of exception and the systematic use of executive orders have not served to provide relief and recovery for the people, but rather, have facilitated corruption, disinformation and chaotic management of the crisis, and enabled disaster capitalism.

\section{Corruption and State-Corporate Crimes Amid the COVID-19 Pandemic}

The governmental handling of the multi-layered crisis has manufactured a twofold criminogenic scenario in the wake of COVID-19. First, the tax incentive policies created to promote economic development and tackle the economic and financial crisis generated the regime of permission for pharmaceutical corporations to profit and extract wealth from the pandemic without addressing PR's needs. This has also undermined PR's budgetary ability to react to the economic impact of the 
COVID-19 pandemic. Second, the uses of the internal state of exception have provided the local elites, members of government and local corporations with the legal framework to continue legitimating practices of disaster capitalism and wealth extraction.

Looking at the first, the U.S. and P.R. governments manufactured a regime of permission that allowed transnational corporations, such as Abbott and Roche, to profit from COVID-19 without exercising any sort of social responsibility. That is, despite the P.R. government having provided corporate welfare for the pharmaceuticals to strive, even in times of economic crisis and disasters, these corporations did not provide PR with the necessary equipment to tackle the pandemic, and even placed the island at the end of the distribution list (Dennis 2020b).

It is important to note that, as previously mentioned, while PR lacked testing, PPE and medical equipment to address the pandemic, these corporations were producing massive amounts of test-kits and medical equipment (Dennis 2020b). As early as March 12, Roche received authorisation from the Food and Drug Administration (FDA) to distribute its molecular tests. Dennis (2020b) reveals that four days later, Roche announced the start of its distribution in the US with the shipment of 400,000 test-kits. Similarly, on March 18, Abbott announced that it received authorisation from the FDA to distribute its molecular test (Dennis, 2020b). Later on, Abbott announced that it had sent over a million molecular tests to all 50 states, however, none of these tests reached PR. Additionally, in the case of the distribution of the reagents necessary to analyse the tests, Dennis (2020b) informs us of the scarcity and slowness with which Roche sent its products to PR. The author argues that:

the fact that PR projects to have low levels of contagion, due to the small number of tests carried out, has implied that Roche has the island at the end of the reagent distribution list. In this way Roche contributed to a vicious circle, where there are not enough tests to know the real level of contagion, and since not enough tests have been done, then the necessary reagents are not sent to process the tests because the supposed level of contagion is low (Dennis 2020b: 6).

The lack of social responsibility of these corporations in PR is striking, especially when both corporations have been profiting from PR's tax-haven-like economy and permissive environmental regulation. Dennis (2020b) shows that a significant part of the \$3.6 billion net profits reported by Abbott in 2019 were earnings produced in PR. Similarly, Roche reported having generated profits of up to $\$ 14.5$ billion in 2019 (Dennis 2020b). While these corporations continue generating exorbitant wealth, and Puerto Ricans continue paying for corporate welfare, the COVID-19 crisis has raised some discussion at the federal level about using PR as 
a strategic place for U.S. pharma to operate (Dennis 2020b) ${ }^{36}$ Some local and U.S. politicians have been vocal about giving pharma yet more tax exemptions. However, not a single word has been said about the pharmaceutical industry's absence in PR's efforts to combat the pandemic. All of this problematises the role Abbott and Roche play in PR's COVID-19 crisis (Dennis 2020b).

The second criminogenic dynamic taking place in PR is the alleged cases of corruption and the irregularities in the procurement of medical equipment. Since the state of emergency was declared in March 12, 2020, the purchase of COVID-19 test-kits, medical equipment and PPE to manage the emergency has been plagued by irregularities involving members of the executive branch, the Medical Task Force, the P.R. National Guard and the private sector. Over $\$ 45$ million in public funds has been spent in the midst of the emergency under irregular circumstances (Cintrón and Valentín 2020). Much of the spending has been under the legal framework of OE-2020-24 of March 16, 2020, which deregulates the procurement and compliance processes in the purchase of medical equipment to address the pandemic.

The irregularities were first denounced by former interim Secretary of Health Concepción Quiñones de Longo, after resigning on March 26, 2020. Later on, the Puerto Rican House of Representatives (PRHR) investigated the allegations made by Quiñones in a series of public hearings, and published a Report in June 29, $2020 .{ }^{37}$ The PRHR identified the following pattern of irregularities and negligence in the management of the pandemic: (1) the irregular and fraudulent procurement of medical equipment; (2) the role of governmental employees in the purchase of medical equipment; and (3) the effects of fraudulent transactions in PR's preparedness for the pandemic. It is interesting to note that the report does not mention the revolving doors, or that many of those involved in these transactions were former governmental employees with close ties to the ruling party (New Progressive Party). Similarly, the emphasis of this report is purely individualistic and ignores the regime of permission that normalised corruption and state-corporate crimes.

There are three major purchases of COVID-19 antibody screening tests and medical equipment. These transactions aimed to acquire more than 1.1 million rapid tests from local suppliers: Castro Business, Apex General Contractors and 313 LLC. None of the transactions were completed as agreed, and only one has been cancelled. In the end, just over 10,000 tests-kits of the 1.1 million purchased finally arrived at health centres and hospitals. As Cintrón and Valentín (2020) point out, all of these purchases followed the same scheme: the P.R. government did not go directly to the manufacturer, but through various layers of "private" intermediaries or corporations, some local and linked to the New Progressive Party, and others foreigner (mostly U.S.-based) with businesses on the island and beneficiaries of tax incentives. Through this chain, all levels earn money: the business front, the partners, the intermediaries and the manufacturer. 
The first issue identified in the report is that the government acquired test-kits without taking the necessary precautions regarding their reliability. An example of this was the purchase of 50,000 test-kits for $\$ 650,000.00$ (\$13.00 each) from Castro Business. ${ }^{38}$ The Department of Health has been unable to use the testkits, since they do not have FDA approval (Valentín and Cintrón 2020). Interestingly, Valentín and Cintrón (2020) argue that Castro Business used a series of intermediary corporations based in the US, Australia and China. Castro Business delivered a quarter of its order of tests-kits, which was subsequently withdrawn from the market. The rest of the order was late and of a different brand than the one agreed upon initially. In the end, only 8,900 tests sold by Castro Business reached the hands of the Department of Health (Valentín and Cintrón 2020).

Second, the report identified the mishandling of public funds. This is the case with two purchase orders for 100,000 test-kits amounting to $\$ 3.6$ million made by 313 LLC. ${ }^{39}$ Despite the corporation requiring the prepayment of 60 percent of the amount owed, the government of PR paid 100 percent of the bill before receiving the test-kits. The corporation followed the same Castro Business scheme, that is, connections in the P.R. government and the ruling party, local and international intermediaries and untested test-kits (Valentín and Cintrón 2020). 313 LLC promised that it would turn in all of the test-kits $(101,500)$ before April 6, 2020 (Valentín and Cintron 2020), however, it only delivered 1,000. The test-kits did not have FDA approval either, but the Department of Health distributed them to different hospitals. Although late, in mid-April, 313 LLC attempted to deliver the remaining test-kits, but the Department of Health declined to receive them until the initial purchase price was reduced (\$45.00 each). 313 LLC finally sued the government to force it to receive tests without changing the terms of payment, since the delay was allegedly due to the FDA. As the case is settled, the \$3.6 million that the Department of Health paid for the test-kits continues in the bank accounts of 313 LLC (Valentín and Cintrón 2020).

Third, overpricing and the non-deliverance of products were identified. This is the case of Apex General Contractors, to which the government paid, in advance, $\$ 38$ million for one million test-kits. This is the case of the above-mentioned conversation, in which Juan Maldonado celebrated the productivity of the virus. The case of Juan Maldonado is an example of revolving doors, and the symbiosis between the private and public sector, since he has been back and forth between the private sector and the government since 2009 (Valentín and Cintrón 2020). Apex and Maldonado followed the same scheme of the other suppliers, only this time, there were over seven intermediaries at the local and international levels. Many intermediaries have received tax incentives by the local and U.S. government (see the case of Fortress Global). 
Another example of overpricing is found in the purchase of test-kits from Maitland 175, a corporation based in Florida, US. Although the corporation sold and delivered 200,000 tests, the Department of Health paid between 120 and 420 percent more than the market price for the test-kits (Cintrón and Valentín 2020). In addition to the overpricing, lack of knowledge in the accounting process made the government pay taxes in Florida for the two orders amounting to $\$ 718,584.09$ and $\$ 355,280.00$ each. Maitland 175 was also involved in alleged fraudulent dealings with the P.R. National Guard, which disbursed $\$ 4.3$ million in emergencyrelated purchases between April and June 30 (Cintrón and Valentín 2020).

The report has also shown the involvement of public employees in these alleged fraudulent and corrupt transactions. For example, the president of the Medical Task Force, Dr Segundo Rodríguez, was the lead figure in the purchase order issued to Apex General Contractors (Valentín 2020). The report argues that Rodríguez exceeded his powers, duties and responsibilities, which were limited to carrying out studies, investigations and strategic plans on the handling of the COVID-19 pandemic. Another example is the creation of a Purchasing Team led by the Medical Task Force..$^{40}$ This team was created in parallel to the Purchasing Office of the Department of Health, and it was composed of public employees with ties to the New Progressive Party. The members of the team were key in the irregular procurement of test-kits. As the report mentions, one of the key issues with this purchasing team is that it did not have the preparation, experience or ability to handle specialised and sensitive purchases, such as test-kits, PPE and ventilators.

The irregular and corrupt handling of the pandemic exacerbated PR's vulnerability and left hospitals unprepared to treat COVID-19 patients. Similarly, despite the public funds spent, and the fact that two of the major producers of COVID-19 equipment are based in PR, the island still lacks test-kits, ventilators and PPE for first responders. Additionally, as Wiscovitch and Sosa (2020) show, these resources and public funds could have been directed to the public health system. Nevertheless, these cases of corruption do not take place in a vacuum, but as this paper has shown, the governmental management of the different disasters affecting PR since 2016 has manufactured a regime of permission that normalised corruption as administrative ethos.

\section{Conclusion}

This paper aimed to elucidate three important aspects of the current management of the pandemic. First, the uses of the state of exception and executive orders to manage the COVID-19 pandemic, and its social, health and economic consequences, are embedded in long-standing legal and disaster management practices 
that I have called the internal state of exception. That is, a normalised state of exception. These antidemocratic and proto-authoritarian practices included the normalisation of the suspension of the rule of law, the systemic violation of human rights and police violence. However, it is important to notice that in every instance, these disaster management techniques are exponentially amplified or expanded. A telling instance is that Governor Vázquez has overreached in her use of executive orders and imposed draconian emergency measures, such as the approval of Law 35 , which criminalises the spread of "misinformation during periods of crisis" and any breach of an executive order.

Second, the Puerto Rican case shows how the uses of the state of exception create a regime of permission or legal framework that facilitates corruption and state-corporate crimes. Using the framework of the regime of permission, this paper shows how the colonial structure and multi-layered crisis created the perfect scenario for corruption, state-corporate crimes and criminal negligence. That is, Abbott and Roche would not be able to make huge profits in PR without the tax incentives and corporate welfare. Similarly, the local elites and members of government used the deregulation of procurement and constricting private services provided by the declaration of the state of emergency to engage in predatory capitalist practices. This analysis shows that corruption in the management of the COVID-19 pandemic, as in previous crises, is a fundamental part of the structure of colonial-neoliberalism in PR. Therefore, the structural dynamics of corruption in recovery and relief efforts drastically exacerbate the impact of crises and, as this paper argues, manufacture further crises and disasters.

Third, this paper shows the dramatic impact that emergency measures to manage the COVID-19 pandemic, and corruption and state-corporate crimes, have on specific populations, and how these negative consequences are embedded in structural violence, inequalities, long-lasting dynamics of power, oppression and organised abandonment. ${ }^{41}$ As it has been well established, COVID-19, as with many other disasters, is affecting mostly poor people of colour, precarious workers, the elderly, migrants, women, queer communities and the unhoused. However, colonised subjects, too often a forgotten category in this amalgam of oppression, have been enduring wave after wave of disaster.

In this sense, it is worth noticing that, although this paper did not engage with an analysis of the resistances to governmental abandonment and negligence, multiple Puerto Rican grassroot and community organisations and socio-political mobilisations have been taking place during the pandemic. From collective kitchens, feminist pantries, unions, community-based environmental movements to collective mobilisations, Puerto Ricans have been facing the pandemic, building solidarity and communal systems of care and protection, and reimagining alternative futures to the systemic abandonment. Therefore, despite this paper being 
focused on state-centred practices of oppression, it is important not to ignore the Puerto Rican experiences and long trajectory of resisting disaster, colonialism, corruption and state-corporate crimes.

\section{Notes}

1. PR is a U.S. unincorporated territory or colony since 1898 . For a detailed analysis of the colonial and sociolegal history of PR see Atiles (2016b).

2. See: www.cidrap.umn.edu/news-perspective/2020/06/puerto-rico-14-states-see-record-covid-19cases (accessed 12 August 2020).

3. My translation from Spanish. For more details see: www.elnuevodia.com/noticias/locales/notas/ wanda-vazquez-insiste-que-el-aumento-en-contagios-por-covid-19-no-es-responsabilidad-delgobierno/ (accessed 12 August 2020).

4. As Dennis (2020b: 8) has shown, "PR had the lowest rate of tests done when compared to anywhere in the US; and according to a study published by the Blavatnik School of Government at the University of Oxford, PR is among the countries least prepared to reopen its economy".

5. These included: maintaining the ongoing curfew from $10 \mathrm{pm}$ to $5 \mathrm{am}$; the prohibition of alcohol sales after $7 \mathrm{pm}$; limiting the capacity of restaurants to 50 percent; among others.

6. For update information visit www.salud.gov.pr/Pages/coronavirus.aspx (accessed October 9, 2020)

7. Including executive order OE-2020- 76 of October 1, 2020.

8. All the executive orders are available in: www.estado.pr.gov/es/ordenes-ejecutivas/ (accessed October 22, 2020).

9. This is an unprecedented use of executive orders to evade legislative oversight, even in time of crisis (see Atiles 2020), and constitutes an clear overreach on the executive powers by the local government.

10. My translation from Spanish. "The virus was productive", was the phrase with which, by text message, Juan Maldonado announced to Roberto Rodríguez López, owner of Apex General Contractors, on the night of March 26, that he had been awarded the above-mentioned contract. For more details see: www.elnuevodia.com/noticias/locales/notas/el-virus-fue-productivo-men sajes-de-texto-entre-dueno-de-apex-y-juan-maldonado/ (accessed 12 August 2020).

11. Here I am following Whyte's (2014) conceptualisation of regime of permission and moment of rupture.

12. For an in-depth analysis of the different emergency measures taken by global north and south countries, see the excellent work conducted by the International State Crime Initiative: http:// statecrime.org/covid19/

13. See Gallego et al. (2020). See also: www.transparency.org/en/news/corruption-and-the-corona virus (accessed 12 August 2020).

14. See for example Cercel et al. (2020), Gerstle and Isaac (2020) and Neal (2019).

15. For an in-depth analysis of the processes of normalisation and transformation of the state of exception in a dispositive of governance see Atiles (2016b), Atiles and Whyte (2018) and Reynolds (2017).

16. In this paper, I do not engage in a study of corporate crime in the pharmaceutical industry per se, but rather, I will show how tax exemptions and deregulation of this sector by the U.S. and P.R. governments undermined PR's capacity to react to crises and disaster. The role of the pharmaceutical industry in state-corporate crimes, corruption and crimes of the powerful has been largely study by authors such as Braithwaite (1984), Griffin et al. (2008) and Rawlison (2017). 
17. For an in-depth analysis of disaster capitalism and the role of emergency administrators see Klein (2007).

18. See: www.bloomberg.com/news/articles/2020-05-14/covid-19-may-cost-puerto-rico-2-billion-intaxes-board-says (accessed 12 August 2020).

19. See: www.estudiostecnicos.com/pdf/Update-COVID-3-ENG-May-18.pdf (accessed 12 August 2020).

20. See: Census QuickFacts: Puerto Rico, www.census.gov/quickfacts/PR (accessed 12 August 2020).

21. See: "Children in poverty (100 percent poverty) in Puerto Rico,"

https://datacenter.kidscount.org/data/tables/43-children-in-poverty-100-percent- poverty?loc=53 \&loct=4\#detailed/4/any/false/37,871,870,573,869,36,868,867,133,38/any/321,322 (accessed 12 August 2020).

22. Garriga-López (2020) has coined the concept of compounded disaster to refer to this multiplicity of disaster affecting PR. Similarly, Bonilla (2020) has coined the concept of coloniality of disaster to describe the multiplicity of disasters affecting PR.

23. 26 U.S. Code $\S 936$ - Puerto Rico and possession tax credit. The law came to an end on December 31, 2005.

24. Among others the following pharmaceutical corporations operate in PR: Abbott, Pfizer, Abbvie, Baxter, Bristol Myers Squibb, Eli Lilly, Johnson \& Johnson and Roche.

25. I am following Cooper and Whyte (2017).

26. This is ten times higher than that of the average U.S. state $(\$ 1,419)$, and nearly three times higher than that of the highest U.S. state $(\$ 5,491)$ (Bhatti and Sloan 2017).

27. See: http://periodismoinvestigativo.com/2019/07/las-889-paginas-de-telegram-entre-rossellonevares-y-sus-allegados/ (accessed 12 August 2020).

28. Law 5 made a legislative declaration of the state of fiscal emergency, legitimating internal state of exception as the legal framework to deal with crises and disasters.

29. Currently, Governor Vázquez and members of her government are under investigation for irregularities in the distribution of aid after the earthquakes and criminal mishandling of this disaster.

30. The executive orders are: OE-2020-23; OE-2020-29; OE-2020-32; OE-2020-33; OE-2020-34; OE-2020-38; OE-2020-041; OE-2020-044; OE-2020-48; OE-2020-52; OE-2020; 54; OE-202060; OE-2020-62; OE-2020-64; OE-2020-66; OE-2020-76; OE-2020-77.

31. S.3548 - 116th Congress (2019-2020) Coronavirus Aid, Relief, and Economic Security Act or the CARES Act.

32. Simultaneously, the P.R. legislature passed Law 43 of April 16, 2020, which establishes as public policy that the treatment of COVID-19 should be free. However, as Wiscovitch and Sosa (2020) have shown, hospitals are still charging COVID-19 patients.

33. The P.R. police had issued over 3,000 fines and arrested over 900 people in connection with alleged curfew violations. See: www.elnuevodia.com/noticias/seguridad/nota/lapoliciaemitesobre2000 denunciasporviolacionaltoquedequeda-2571567/ (accessed 12 August 2020).

34. Sosa and Wiscovitch (2020) have pointed out at this point there is no clear reporting of the numbers of dead generated by COVID-19.

35. The open economy invocated by this executive order has been maintained in the following executive orders.

36. See: www.industryweek.com/the-economy/article/21132824/puerto-ricos-pharma-push (accessed 12 August 2020).

37. See: R. de la C. 1741 June 29, 2020. This report came out at the same time another report (R. de La C. 1696 of June 20,2020) in which the PRHR investigated the cases of corruption and criminal negligence surrounding the management of the swarm of earthquakes. Additionally, on July 3 , the 
Department of Justice concluded an investigation on the management of the swarm of earthquakes and make a recommendation that Governor Wanda Vázquez should be investigated for six charges of corruption, plus negligence.

38. Castro Business is a local corporation specialising in food distribution and with contracts with the P.R. government and the P.R. National Guard since 2008 (Valentín and Cintrón 2020).

39. 313 LLC and its president, Ricardo Vázquez Hernández, had received tax incentives and exceptions from the P.R. government in areas ranging from legal advice to the video games and electronics industry.

40. The team was composed by Mabel Cabeza (Department of Health and Governor Office), Adil Rosa (subsecretary of the Department of Health) and Mariel Rivera (Department of Health Purchasing).

41. Tombs (2016) has developed a similar analysis with the concept of social murder.

\section{References}

Agamben, G. (2005) State of Exception (Homo Sacer II, 1). Chicago: University of Chicago.

Agamben, G. (2020) "Clarifications", European Journal of Psychoanalysis. Available online at: www. journal-psychoanalysis.eu/coronavirus-and-philosophers/ (accessed 12 August 2020).

Appadurai, A. (2020) “The COVID exception”, Social Anthropology, 28(2): 221-222.

Aronoff, K. (2017) "There's a shady Puerto Rico Contract you didn't hear about", The Intercept, 31 October. Available online at: https://theintercept.com/2017/10/31/puerto-rico-electric-contractcobra/ accessed (12 August 2020).

Atiles, J. (2016a) "Colonial State Terror in Puerto Rico: A Research Agenda", State Crime, 5(2): $221-242$.

Atiles, J. (2016b) Apuntes para abandonar el derecho: Estado de excepción colonial en Puerto Rico. Cabo Rojo, PR: Editora Educación Emergente.

Atiles, J. (2018) "Colonial State of Exception as Economic Policy: A Socio-Legal Analysis of the Puerto Rican Case", Oñati Socio-Legal Series, 8(6): 819-844.

Atiles, J. (2020) "Exceptionality and Colonial State-Corporate Crime in the Puerto Rican Fiscal and Economic Crisis", Latin American Perspective, 47(3): 49-63.

Atiles, J. and Whyte, D. (2018) "State of Exception, Law and the Economic: A Socio-Legal Approach to the Economy State of Exception in an Era of Crisis", Oñati Socio-Legal Series, 8(6): 808-818.

Balmaceda, J. (2020a) "Long in Recession, Puerto Rico Needs More than Just COVID-19 Relief to Overcome its Crises", Center on Budged and Policy Priorities, 7 May. Available online at: www. cbpp.org/research/economy/long-in-recession-puerto-rico-needs-more-than-just-covid-19-reliefto-overcome-its accessed (12 August 2020).

Balmaceda, J. (2020b) "Without a Boost in Next COVID-19 Relief Bill, Puerto Rico Faces Deep Food Aid Cut", Center on Budged and Policy Priorities, 28 July. Available online at: www.cbpp.org/ blog/without-boost-in-next-covid-19-relief-bill-puerto-rico-faces-deep-food-aid-cuts (accessed 12 August 2020).

Bhatti, S. and Sloan, C. (2017) "Broken promise. PROMESA is a mode for undermining democracy and pushing austerity elsewhere in the U.S.", ReFund America Project. Available online at: www. refundproject.org/\#puerto-rico (accessed 12 August 2020).

Bonilla, Y. (2020) "The Coloniality of Disaster: Race, Empire, and the Temporal Logic of Emergency in Puerto Rico, USA”, Political Geography, 78: 102-181. 
Bonilla, Y. and LeBrón, M. (2019) Aftershocks of Disaster: Puerto Rico Before and After the Storm. Chicago: Haymarket Books.

Braithwaite, J. (1984) Corporate Crimes in the Pharmaceutical Industry. London: Routledge.

Cercel, C., Fusco, G. and Lavis, S. (eds) (2020) State of Exception: Law, History, Theory. New York: Routledge.

Cintrón, J. and Valentín, L (2020) "Salud compró equipo medico a sobreprecio a contacto referido por la Guardia Naciona", Centro Periodismo Investigativo, 23 July. Available online at: https:// periodismoinvestigativo.com/2020/07/salud-compro-equipo-medico-a-sobreprecio-a-contactoreferido-por-la-guardia-nacional/\# (accessed 12 August 2020).

Comision de Derecho Civiles (2020) "Declaraciones de la Comisión de Derechos Civiles en torno a las Órdenes Ejecutivas y el COVID-19”. Available online at: www.cdc.pr.gov/SalaPrensa/Documents/ Declaraciones\%20de\%201a\%20Comision\%20de\%20Derechos\%20Civiles\%20en \%20torno $\% 20$ a\%20las\%20Ordenes\%20Ejecutivas\%20y\%20el\%20COVID-19.pdf (accessed 12 August 2020).

Cooper, V. and Whyte, D. (eds) (2017) The Violence of Austerity. London: Pluto Press.

Dennis, A. (2020a) "COVID-19 and the Collapse of Private Hospitals in PR", Eye on the Ties, 9 April. Available online at: https://news.littlesis.org/2020/04/09/covid-19-and-the-collapse-of-private-hos pitals-in-puerto-rico/ (accessed 12 August 2020).

Dennis, A. (2020b) "Pain and Profit: COVID-19 Profiteers in Puerto Rico", Hedgepapers, No. 72, 30 July. Available online at: http://hedgeclippers.org/pain-and-profit-covid-19-profiteers-in-puertorico/ (accessed 12 August 2020).

Florido, A. (2020) "Advocate for The Poor in Puerto Rico Is Released After Arrest During Protest", NPR, 30 April. Available online at: www.npr.org/2020/04/30/848684061/puerto-rico-policearrest-advocate-for-the-poor (accessed 12 August 2020).

Gallego. J., Prem, M., and Vargas, J. (2020) "Corruption in the Times of Pandemia", The Latin American and Caribbean Economic Association. Available online at: https://ideas.repec.org/p/ col/000518/018164.html (accessed 12 August 2020).

GAO (2018) "Puerto Rico. Factors Contributing to the Debt Crisis and Potential Federal Actions to Address Them. A Report to Congressional Committees". GAO-18-387.

Garriga-López, A. M. (2020) "Compounded Disaster: Puerto Rico Confront COVID-19 under US Colonialism", Social Anthropology, 28(2): 269-270.

Gelardi, C. (2020) "Colonialism Made Puerto Rico Vulnerable to Coronavirus Catastrophe", The Nation, 9 April. Available online at: www.thenation.com/article/politics/puerto-rico-corona virus/?print=1 (accessed 12 August 2020).

Gerstle, G. and Isaac, J. (eds.) (2020) State of Exception in American History. Chicago: University of Chicago Press.

Green, P. and Ward, T. (2004) State Crime: Government, Violence and Corruption. London: Pluto.

Griffin, O. and Miller, B. (2011) "OxyContin and a Regulation Deficiency of the Pharmaceutical Industry: Rethinking State-Corporate Crime", Critical Criminology, 19(3): 213-226.

Hedge Clippers (2016) "Pirates of the Caribbean", Report 3(3). Available online at: http://hedgeclip pers.org/wp-content/uploads/2016/12/20161025_Hedgeclippers_ReportPR_v3-3.pdf (accessed 12 August 2020).

Jiménez, M. (2020) "Puerto Rico under the Colonial Gaze: Oppression, Resistance and the Myth of the Nationalist Enemy", Latino Studies, 18(1): 27-44.

Kilometro Cero (2018) "Skill over force. A critical analysis of the use-of-force statistics of the Puerto Rico Police against the people". Available online at: https://drive.google.com/file/d/0B3p2 WlC_-VLibEJjc2pxZjZibWZvbGtBczNzdHVRS1JvNIU0/view accessed 12 August 2020). 
Kilometro Cero (2020) "Documentación de intervenciones y casos de uso de fuerza de la policía durante las protestas Wanda renuncia". Available online at: https://docs.google.com/document/d/1 FoPzYOVckahXGU19MBba2QOzGcT3wblCouXNXxdGXXg/edit\#heading=h.rgldnspa1ad3 (accessed 12 August 2020).

Kishore, N., Marqués, D., Mahmud, A. et al. (2018) "Mortality in Puerto Rico after Hurricane Maria", The New England Journal of Medicine, 379: 162-170.

Klein, N. (2007) The Shock Doctrine: The Rise of Disaster Capitalism. London: Penguin.

Klein, N. (2018) The Battle for Paradise. Puerto Rico takes on the Disaster Capitalists. Chicago: Haymarket Books.

Lasslett, K. (2012) "State Crimes by Proxy: Australia and Bougainville Conflict", British Journal of Criminology, 52: 705-723.

Maitra, A. (2020) "COVID-19 and the Neoliberal State of Exception", Common Dreams, 30 March. Available online at: www.commondreams.org/views/2020/03/30/covid-19-and-neoliberal-stateexception (accessed 12 August 2020).

Martinez, E. (2020) "Puerto Rico never set up an information network to gather data on COVID19", Centro Periodismo Investigativo, 4 May. Available online at: https://periodismoinvestiga tivo.com/2020/05/puerto-rico-never-set-up-an-information-network-to-gather-data-on-covid-19/ (accessed 12 August 2020).

Michalowski, R. and Kramer, R. (2006) State-Corporate Crime. New Jersey: Rutgers University Press.

Neal, A. (2019) Security as Politics: Beyond the State of Exception. Edinburgh: Edinburgh University Press.

Ong, A. (2006) Neoliberalism as Exception: Mutations in Citizenship and Sovereignty. Durham: Duke University Press.

Onís, C., Lloréns, H. and Santiago, R. (2020) "Puerto Rico's Seismic Shocks", NACLA, 15 January. Available online at: https://nacla.org/news/2020/01/14/puerto-rico-earthquakes-renewable-energy (accessed 12 August 2020).

Pearce, F. (1976) Crime of The Powerful: Marxism, Crime and Deviance. London: Pluto Press.

Rawlinson, P. (2017) "Immunity and Impunity: Corruption in the State-Pharma Nexus", International Journal for Crime, Justice and Social Democracy, 6(4): 86-99.

Reynolds, J. (2017) Empire, Emergency and the International Law. Cambridge: Cambridge University Press.

Rodriguez, V. (2020) "Más atrasos en el proceso de recuperación tras el huracán María debido a señalamientos federales", Centro de Periodismo Investigativo, 30 July. Available online at: https:// periodismoinvestigativo.com/2020/07/mas-atrasos-en-el-proceso-de-recuperacion-tras-el-hura can-maria-debido-a-senalamientos-federales/ (accessed 12 August 2020).

Serrano, A. (2020) "PR Department of Health Still has Problems Producing Correct and Update COVID-19 Data", Centro Periodismo Investigativo, 29 May. Available online at: https://periodis moinvestigativo.com/2020/05/pr-department-of-health-still-has-problems-producing-correct-andupdated-covid-19-data/ (accessed 12 August 2020).

Sosa, O. and Wiscovitch, J. (2020) "More Death in Puerto Rico than Announced During the Pandemic", Centro de Periodismo Investigativo, 15 June. Available online at: https://periodismoinvestigativo. com/2020/06/more-deaths-in-puerto-rico-than-announced-during-the-pandemic/ (accessed 12 August 2020).

Tombs, S. (2016) Social Protection After the Crisis: Regulation Without Enforcement. Bristol: Policy Press. 
Valentín, L. (2020) "Otro vendedor de pruebas de COVID-19 referido a salud por el Task Force y Mabel Cabeza", Centro Periodismo Investigativo, 7 May. Available online at: https://periodismoin vestigativo.com/2020/05/otro-vendedor-de-pruebas-de-covid-19-referido-a-salud-por-el-taskforce-y-mabel-cabeza/ (accessed 12 August 2020).

Valentín, L. and Cintrón, J. (2020) "El esquema de la venta de pruebas en PR", Centro de Periodismo Investigativo, 28 May. Available online at: https://periodismoinvestigativo.com/2020/05/elesquema-de-la-venta-de-pruebas-en-puerto-rico/(accessed 12 August 2020).

Valentín, L. and Minet, C. (2020) "Puerto Rico Health Department's COVID-19 Math is Wrong", Centre Periodismo Investigativo, 18 April. Available online at: https://periodismoinvestigativo. com/2020/04/puerto-rico-health-departments-covid-19-math-is-wrong/ (accessed 12 August 2020).

Wiscovitch, J. and Sosa, O. (2020) "Puerto Rico's Chronically Ill Health System Blocks Effective COVID-19 Response", Centro Periodismo Investigativo, 24 July. Available online at: https://perio dismoinvestigativo.com/2020/07/puerto-ricos-chronically-ill-health-system-blocks-effectivecovid-19-response/ (accessed 12 August 2020).

Whyte, D. (2007) “The Crimes of Neoliberal Rule in Occupied Iraq", British Journal of Criminology, 47: 177-195.

Whyte, D. (2009) Crimes of The Powerful: A Reader. London: Open University Press.

Whyte, D. (2010) "The Neo-Liberal State of Exception in Occupied Iraq", in Chambliss, W., Michalowski R. and Kramer, R. (eds) State Crime in the Global Age. Devon and Portland: William Publishing, 134-151.

Whyte, D. (2014) "Regimes of Permission and State-Corporate Crimes", State Crime Journal, 3(2): 237-246.

Whyte, D. (ed.) (2015) How Corrupt is Britain? London: Pluto. 